\begin{tabular}{|c|c|c|c|c|c|c|}
\hline \multirow{4}{*}{ Impact Factor: } & ISRA (India) & $=3.117$ & SIS (USA) & $=0.912$ & ICV (Poland) & $=6.630$ \\
\hline & ISI (Dubai, UAI & $=0.829$ & РИНЦ (Russia) & $=0.156$ & PIF (India) & $=1.940$ \\
\hline & GIF (Australia) & $=0.564$ & ESJI (KZ) & $=5.015$ & IBI (India) & $=4.260$ \\
\hline & JIF & $=1.500$ & SJIF (Morocco) & $=5.667$ & & \\
\hline
\end{tabular}

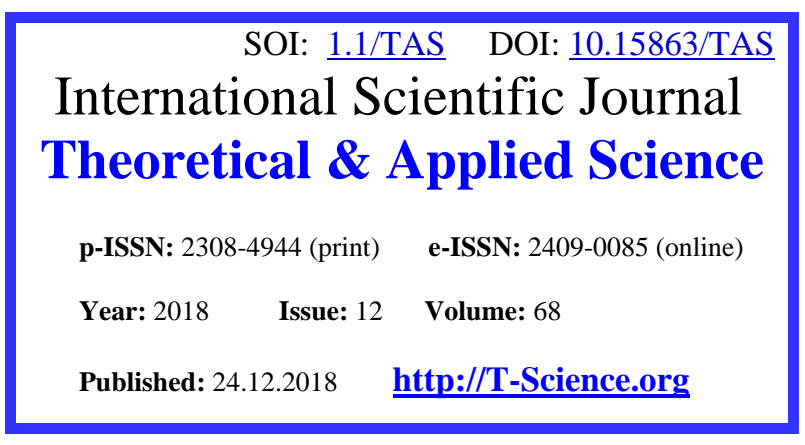

SECTION 32. Jurisprudence.
QR - Issue

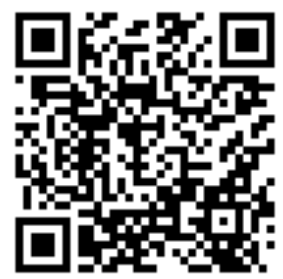

QR - Article

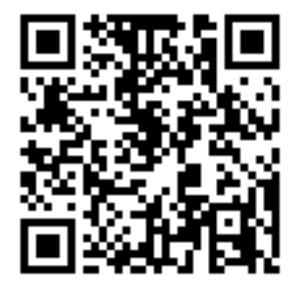

R.T. Ismailov

chief of the cathedra of criminal law and prevention of crime in Academy of Ministry of Internal Affairs of the Kyrgyz Republic candidate of law, colonel of militia

Asel Manapovna Tagaeva professor of cathedra criminology, psychology and special equipment, in Academy of Ministry of Internal Affairs of the Kyrgyz Republic candidate of law, colonel of militia

\title{
FOREIGN CRIMINAL OFFENSION (CRIME, CONDUCT): THEORY AND NEW LAW OF THE KYRGYZ REPUBLIC
}

Abstract: The article raises topical issues of the divergence of the theory of criminal law with the new criminal law and the law on misconduct of the Kyrgyz Republic regarding continuing criminal offenses (crimes, misconduct).

Key words: completed crime, completed offense, lasting crime, lasting offense, lasting offense, art. 20 of the Criminal Code, Art. 16 of the Code of Misconduct of the Kyrgyz Republic.

Language: Russian

Citation: Ismailov, R. T., \& Tagaeva, A. M. (2018). Foreign criminal offension (crime, conduct): Theory and new law of the Kyrgyz republic. ISJ Theoretical \& Applied Science, 12 (68), 220-223.

Soi: $\underline{\text { http://s-o-i.org/1.1/TAS-12-68-31 Doi: crossef https://dx.doi.org/10.15863/TAS.2018.12.68.31 }}$

\section{ДЛЯЩЕЕСЯ УГОЛОВНОЕ ПРАВОНАРУШЕНИЕ (ПРЕСТУПЛЕНИЕ, ПРОСТУПОК): ТЕОРИЯ И НОВОЕ ЗАКОНОДАТЕЛЬСТВО КЫРГЫЗСКОЙ РЕСПУБЛИКИ}

Аннотация: В статье поднимаются актуальные вопросы расхождения теории уголовного права с новым уголовным законодательством и законодательством о проступках Кыргызской Республики относительно длящихся уголовных правонарушений (преступлений, проступков).

Ключевые слова: оконченное преступление, оконченный проступок, длящееся преступление, длящийся проступок, длящееся правонарушение, cm. 20 УК КP, ст. 16 Кодекса о проступках КР.

\section{Introduction}

Противоправное деяние между его началом и окончанием имеет разную протяженность, которая позволяет подразделять действия по времени на преступления и проступки (далее уголовные правонарушения, правонарушения): 1) одномоментные; 2) разномоментные; 3) продолжаемые; 4) с отдаленным результатом; 5) длящиеся. Однако в рамках нашей темы акцентируем внимание лишь на понятии и моменте окончания таких видов уголовных правонарушений как длящиеся.

\section{Materials and Methods}

Длящееся уголовное правонарушение в теории уголовного права относится к разновидности сложного единичного правонарушения. В свою очередь разграничение сложных единичных правонарушений, в частности длящихся, от множественности правонарушений является довольно сложным процессом [1, с.242], что, как нам представляется, связано с неоднозначностью определения момента его окончания. Между тем, само определение оконченного правонарушения, в теории уголовного права также подлежит критике [2, с. 21]. От точного установления момента, когда правонарушение считается 


\begin{tabular}{|c|c|c|c|c|c|c|}
\hline \multirow{4}{*}{ Impact Factor: } & ISRA (India) & $=3.117$ & SIS (USA) & $=0.912$ & ICV (Poland) & $=6.630$ \\
\hline & ISI (Dubai, UAE & $=0.829$ & РИНЦ (Russia) & $=0.156$ & PIF (India) & $=1.940$ \\
\hline & GIF (Australia) & $=0.564$ & ESJI (KZ) & $=5.015$ & IBI (India) & $=4.260$ \\
\hline & JIF & $=1.500$ & SJJIF (Morocco) & $=5.667$ & & \\
\hline
\end{tabular}

оконченным, зависит правильная их квалификация, а в конечном итоге, это влияет на соблюдение принципов законности и справедливости.

В совокупности обозначенных проблем понятие длящегося преступления, определение момента его окончания является актуальным для теории уголовного права. Значимость поднятой темы также усиливается в свете принятия в Кыргызской Республики новых кодексов, в частности Уголовного кодекса (далее - УК КР) [3] и Кодекса о проступках [4] (далее - КоП КР).

Еще в середине 19 века теории уголовного права уже было известно понятие длящегося преступления [5, с. 63]. О длящихся преступлениях упоминалось и в Уложении 1845 г., где они назывались «беспрерывно продолжаемыми» [6].

Советскому законодательству эта разновидность сложного единичного преступления неизвестна, однако ею пользовалась судебная практика того периода. В постановлении Пленума Верховного Суда СССР от 4 марта 1929 г. (в редакции Пленума от 14

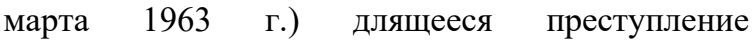
определялось как «действие или бездействие, сопряженное с последующим длительным невыполнением обязанностей, возложенных на виновного законом под угрозой уголовного преследования» [7, с. 6]. Такие преступления совершаются на протяжении более или менее длительного периода [7, с. 6].

В теории уголовного права есть такая точка зрения, что длящиеся правонарушенияпреступления совершаются единым способом. Это совокупность множества действий (бездействий), которые являются звеньями одного и того же действия или бездействия, между ними нет промежутков по времени [5, с. 63], в отличие от продолжаемых преступлений.

Момент окончания этого преступления следует считать действия виновного, направленные на прекращение преступления, или наступления события, препятствующего совершению длящегося преступления, например, явка с повинной субъекта правонарушения, пресечение преступления правоохранительными органами, наступление совершеннолетия детей, которым виновный не платил средств на их содержание [5, с. 64].

В современном уголовном законодательстве и законодательстве о проступках Кыргызской Республики впервые закреплены определения длящихся правонарушений. Так, под «длящимся преступлением признается деяние, предусмотренное Особенной частью настоящего Кодекса, совершение которого начинается с действия или бездействия, которое затем осуществляется непрерывно» (ч. 1 ст. 20 УК КР), аналогичное законодательное определение, применительно к проступку, дается в Кодексе о проступках КР (ч. 1 ст. 16).

Кроме того, в вышеуказанных статьях определен момент окончания данных (длящихся) правонарушений, а именно, они считаются оконченными с момента прекращения действия или бездействия.

Казалось бы, что вышеуказанные понятия применимы, например, к таким преступлениям, ответственность за которые установлена: ст. 123 КоП КР при таком альтернативном противоправном действии как хранение наркотических средств, психотропных веществ, их аналогов и прекурсоров (далее - наркотиков) без цели сбыта в небольших размерах; ст. 349 УК КР «Побег из мест лишения свободы или из-под стражи»; ст. 267 УК КР при хранении наркотических средств, психотропных веществ и их аналогов (далее - наркотиков) в значительном, крупных, особо крупных размерах; ст. 368 УК КР «Дезертирство» и, что, такие правонарушения могут длиться беспрерывно, а считаться оконченными с момента прекращения действия или бездействия, то есть, когда противоправное состояние прервано либо пресечением со стороны правоохранительных органов или явкой с повинной субъекта правонарушения.

Однако следует заметить, что длящиеся правонарушения являются правонарушениями с формальным составом и первоначальный момент таких деяний уже образует оконченный состав уголовного правонарушения. Поэтому вряд ли можно согласиться с утверждением некоторых авторов [8, с. 11], что якобы длящиеся правонарушения признаются оконченными с момента прекращения преступного (противоправного) состояния. По этому поводу, следует согласиться с точкой зрения Корнеевой A.В., что сторонниками вышеуказанного утверждения производится подмена, смешение юридического момента окончания уголовного правонарушения и фактического [9, с. 83]. Фактически данные уголовные правонарушения считаются оконченными с прекращения противоправного (преступного) состояния по воле либо вопреки воле субъекта правонарушения, однако юридически это не так. Для юридического признания правонарушения оконченным, с учетом того, что они (длящиеся правонарушения) относятся к формальным составам, достаточно первоначального момента деяния.

Таким образом, юридически такие виды правонарушений как: хранение наркотиков в небольших размерах (ст. 123 КоП КР), в значительном, крупных, особо крупных размерах (ст. 267 УК КР), считаются оконченными сразу же с момента хранения; побег из мест лишения 


\begin{tabular}{|c|c|c|c|c|c|c|}
\hline \multirow{4}{*}{ Impact Factor: } & ISRA (India) & $=3.117$ & SIS (USA) & $=0.912$ & ICV (Poland) & $=6.630$ \\
\hline & ISI (Dubai, UAE & $=0.829$ & РИНЦ (Russia) & $=0.156$ & PIF (India) & $=1.940$ \\
\hline & GIF (Australia) & $=0.564$ & ESJI (KZ) & $=\mathbf{5 . 0 1 5}$ & IBI (India) & $=4.260$ \\
\hline & JIF & $=1.500$ & SJIF (Morocco) & $=5.667$ & & \\
\hline
\end{tabular}

свободы или из-под стражи (ст. 349 УК КР) - с момента побега; дезертирство (ст. 368 УК КР) - с самого первого дня после тридцати суток самовольного оставления части или места службы и т.д.

Если, например, проанализировать такое правонарушение, как побег, то он рассматривается по общим правилам о возможности покушения в правонарушениях с формальным составом.

Кроме того, проведенный нами анализ отдельных статей УК КР и КоП КР, также указывает на то, что такие виды правонарушений, которые фактически окончены не с момента прекращения действия или бездействия, a c момента достижения максимально допустимого срока для данного деяния времени, например, уклонение родителей от содержания детей (при достижении совершеннолетия) (ст. 77 КоП КР), самовольное оставление части или места службы является проступком в случае если данное действие продолжалось до 10 суток (ст.180 КоП КР), а аналогичное деяние свыше 10 суток, но не более 30 суток признается уже преступлением (ст. 367 УК КР «Самовольное оставление части или места службы»).

Такие правонарушения, как самовольное оставление части или места службы, имею все признаки длящихся правонарушений в теоретическом понимании, однако они не согласуются с законодательным определением, так как в них отсутствует непрерывность. Специфика таких видов фактически длящихся правонарушений, заключается в том, что они длятся в течение «определенного» времени, а оканчиваются (фактически) при прерывании данного деяния именно в этом, установленном законодательством, промежутке [10]. Однако если противоправные правонарушения не прекращаются, то они трансформируются, переходят из одного вида в другой, при этом применительно к предыдущему правонарушению мы не можем говорить о непрерывности его деяния, так как последующие действия (бездействия) являются признаком уже иного правонарушения.

Уклонение родителей от содержания несовершеннолетних детей (ст. 77 КоП КР), также имеет определенный, более или менее длительный промежуток времени (достижении совершеннолетнего возраста детей), при достижении максимального предела которого, преступление фактически считается оконченным. Юридически же данное правонарушение считается таковым (оконченным), с момента уклонения от выплаты на основании судебного решения средств на содержание несовершеннолетних детей.

\section{Conclusion}

Проведенный нами анализ теории и законодательства позволяет сделать следующие выводы:

- в уголовном законодательстве и законодательстве о проступках при определении длящегося преступления и установления момента его окончания за основу было взято фактическое понимание бессрочных длящихся правонарушений (преступления, проступка);

- законодательные определения длящихся правонарушений в ст. 20 УК КР и ст. 16 КоП КР не охватывают все разновидности данных сложных правонарушений, в частности фактически длящихся правонарушений, имеющих максимальный предельный срок;

- не выдерживают критики, как с юридической, так и с фактической позиции положения о моменте окончания длящихся правонарушений, установленные в законодательстве;

- законодательная модель конкретных длящихся правонарушений, с юридической позиции, относится к формальным составам преступлений, поэтому признавать оконченными с юридической позиции их следует не с момента прекращения действия или бездействия, a c «первоначального» момента деяния.

C нашей точки зрения, решение данной проблемы может развиваться в одном из следующих направлений: 1) по пути исключения данных статей из кодексов; 2) по пути редакционной правки вышеуказанных статей.

Первое направления представляется самым простым, для законодателя, но не снимающим теоретические проблемы данного института.

Второе направление требует обоснованную теоретическую основу с учетом обозначенных выше проблем. 


\begin{tabular}{llllll} 
& ISRA (India) $=\mathbf{3 . 1 1 7}$ & SIS (USA) $=\mathbf{0 . 9 1 2}$ & ICV (Poland) & $\mathbf{= 6 . 6 3 0}$ \\
Impact Factor: & ISI (Dubai, UAE) $=\mathbf{0 . 8 2 9}$ & PUHL (Russia) $=\mathbf{0 . 1 5 6}$ & PIF (India) & $=\mathbf{1 . 9 4 0}$ \\
& GIF (Australia) $=\mathbf{0 . 5 6 4}$ & ESJI (KZ) & $\mathbf{5 . 0 1 5}$ & IBI (India) & $=\mathbf{4 . 2 6 0}$ \\
& JIF & $\mathbf{1 . 5 0 0}$ & SJIF (Morocco) $=\mathbf{5 . 6 6 7}$ & & \\
\hline
\end{tabular}

\section{References:}

1. Kudryavtsev, V. N. (2001). Obschaya teoriya kvalifikatsii prestupleniy - 2-e izd., pererab. i dopoln. (p.242). M., Yurist'.

2. Demidov, Y. (1996). Ponyatie okonchennogo prestupleniya. Sovetskaya yustitsiya, \# 16, 21.

3. (2018). Ugolovnyiy kodeks Kyirgyizskoy Respubliki (ot 2 fevralya 2017 goda \# 19). (p.154). Bishkek: M-MAXIMA.

4. (2017). Kodeks Kyirgyizskoy Respubliki o prostupkah (ot 1 fevralya 2017 goda \# 18). (p.110). Bishkek: OsOO M-MAXIMA.

5. (1998). Ugolovnoe pravo Rossii. Uchebnik dlya vuzov. V 2-h tomah. T. 1. Obschaya chast. Otv. red. A.N. Ignatov, Yu.A. Krasikov. (p.63). M.: Izd. gruppa NORMA - INFRA-M

6. (2002). Kurs ugolovnogo prava: V 5 tt: T. 1: Obschaya chast: Uchenie o prestuplenii: Uchebnik dlya vuzov. (p.624). Zertsalo-M.

7. (2005). Postanovlenie 23-go plenuma verhovnogo suda SSSR ot 4 marta 1929 g. Ob usloviyah primeneniya davnosti $i$ amnistii $k$ dlyaschimsya i prodolzhaemyim prestupleniyam (s izmeneniyami, vnesennyimi postanovleniem Plenuma ot 14 marta 1963 g. \# 1) (Sudebnaya praktika po ugolovnyim delam / sost. G.A. Esakov. (p.6). M.: TK Velbi, Izd-vo Prospekt.

8. Sabitov, R. A. (2003). Teoriya $i$ praktika kvalifikatsii ugolovno-pravovyih deyaniy. (p.94). M..

9. Nafiev, S. H., \& Muhamedzyanov, I. A. (1999). Kvalifikatsiya prestupleniy. (p.11). Kazan: Izd-vo Kazan. Un-ta.

10. Korneeva, A. V. (2008). Teoreticheskie osnovyi kvalifikatsii prestupleniy. ucheb. posobie. In: A.I. Raroga (Eds.). (p.83). M.: TK Velbi, Izdvo Prospekt.

11. Kryilov, N. E. (2008). Osnovyi teorii kvalifikatsii prestupleniy. Moscow. 